Discussion Paper No. 14-003

The Effect of Direct Democracy on the Level and Structure of Local Taxes

Zareh Asatryan, Thushyanthan Baskaran, and Friedrich Heinemann

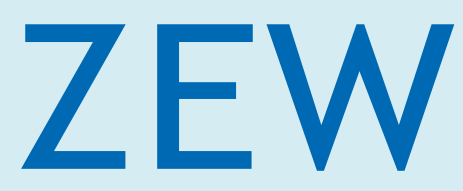

Zentrum für Europäische Wirtschaftsforschung $\mathrm{GmbH}$

Centre for European

Economic Research 
Discussion Paper No. 14-003

\title{
The Effect of Direct Democracy on the Level and Structure of Local Taxes
}

\author{
Zareh Asatryan, Thushyanthan Baskaran, \\ and Friedrich Heinemann
}

Download this ZEW Discussion Paper from our ftp server:

http://ftp.zew.de/pub/zew-docs/dp/dp14003.pdf

Die Discussion Papers dienen einer möglichst schnellen Verbreitung von neueren Forschungsarbeiten des ZEW. Die Beiträge liegen in alleiniger Verantwortung der Autoren und stellen nicht notwendigerweise die Meinung des ZEW dar.

Discussion Papers are intended to make results of ZEW research promptly available to other economists in order to encourage discussion and suggestions for revisions. The authors are solely responsible for the contents which do not necessarily represent the opinion of the ZEW. 


\title{
The Effect of Direct Democracy on
}

\section{the Level and Structure of Local Taxes}

\author{
Zareh Asatryan (ZEW Mannheim and University of Freiburg)* \\ Thushyanthan Baskaran (University of Göttingen) \\ Friedrich Heinemann (ZEW Mannheim and University of Heidelberg)
}

January, 2014

\begin{abstract}
We study the effect of direct democracy on local taxation. Our setting is the German federal state of Bavaria, where in 1995 a state-wide referendum introduced the possibility to initiate direct democratic legislation into the local government code. Relying on a sample of all Bavarian municipalities over the period 1980-2011, we hypothesize that complementing a representative form of government with direct democratic elements leads to (i) higher local tax rates and (ii) a shift of the local tax mix from taxes with broader (property taxes) to taxes with narrower bases (business taxes). For identification, we implement selection on observables and difference-indiscontinuity designs. Our results show that both actual direct democratic activity - measured by the number of initiatives - and the ease with which direct democratic legislation can be implemented - measured by signature and quorum requirements - increase local tax rates and shift the tax mix toward taxes with narrower bases.
\end{abstract}

Keywords: Direct democracy, taxation, regression discontinuity, Bavaria JEL codes: D72, D78, H71

*Corresponding author: Zareh Asatryan, ZEW, L7 1, 68161 Mannheim, Germany; Tel.: (+49)6211235392; Email: asatryan@zew.de

We are grateful to seminar participants at ZEW Mannheim, University of Mannheim, Walter Eucken Institute, European Public Choice Society, International Institute of Public Finance, European Economic Association and Asian Econometric Society for valuable comments. 


\section{Introduction}

Since the 1970s, direct democratic institutions have been identified as potential determinants of budgetary outcomes. The underlying argument is that if voters have the right to bypass parliamentary representatives through direct legislation, the influence of the median voter relative to that of the legislative agenda setter should grow (Pommerehne, 1978; Romer and Rosenthal, 1979). So far this reasoning has been primarily tested empirically with respect to public expenditures and debt.11 On the other hand, the effect of direct democracy on taxation in general and the tax structure in particular, has been largely neglected. To our knowledge, there are only two exceptions: Matsusaka's (2005) study on the impact of voter initiated legislation in US states covers both the expenditure and revenue sides of state budgets. His results suggest that direct democracy leads to higher user charges and lower share of taxes in state revenues. Recently, Feld and Schaltegger (2012) have arrived at similar results for Swiss cantons: cantons where financial referenda are mandatory rely more on user fees than cantons where referenda are optional.

While the results in these studies are suggestive, their results rely ultimately on a selection on observables approach. Hence, it can be questioned whether they have identified a causal effect. In particular, the importance of direct democracy could be systematically related to tax pressure or be a consequence of an unobserved variable like citizen's fiscal preferences (Funk and Gathmann, 2013). Our study addresses this gap in the literature. It is the first analysis of the role of direct democracy in shaping tax policies that relies on a credible identification strategy ${ }^{2}$ For identification, we exploit the 1995 institutional reform of adopting direct democratic legislation at the local level in the German state of Bavaria to test whether the right of initiatives has had an effect on a) the level of municipal taxation (i.e. local tax rates), and b) on the choice between different

\footnotetext{
${ }^{1}$ For a survey of the early literature, see Kirchgässner $(2000)$, for more recent studies, see Feld and Matsusaka (2003); Funk and Gathmann (2011, 2013); Asatryan et al. (2013).

'In contrast, a few studies exist which employ convincing identifications strategies to analyze the link between direct democracy and local expenditures (Asatryan et al., 2013, Hinnerich and PetterssonLidbom, 2012).
} 
municipal tax instruments (i.e. local tax-mix). More specifically, we exploit a combination of the 1995 direct democracy reform together with the size dependent population thresholds on the number of signature and quorum requirements which allows designing a quasi-experimental setup.

With its differentiated analysis for different tax instruments, our study also contributes to the growing literature on the political economy of the observable tax structure in democracies. In the context of this literature, our study is the first to extend the discussion on the political economy of the local tax-mix to the case of German cooperative federalism, which offers an interesting comparison against the existing Swiss and US evidence.

In this literature's underlying theory, the observable tax mix is modeled as the outcome of an optimization process (Hettich and Winer, 1984, 1988, 1999). In the Hettich-Winermodel of representative democracy, self-interested politicians and political parties are maximizing electoral support by minimizing the expected vote losses for collecting any given amount of budget revenue. This suggests that in the equilibrium the decision maker will choose tax rates to equalize the marginal vote losses per unit of taxed revenue across different tax sources. The work by Hettich and Winer has initiated a large body of empirical literature on the political economy of tax structure on the local (e.g. Inman (1989); Gilla and Haurin (2001); Ashworth et al. (2006); Fiva and Rattso (2007); Geys and Revelli (2009); Feld et al. (2010)) as well as national levels (e.g. Winer and Hettich (1991); Volkerink and de Haan (1999); Ashworth and Heyndels (2001, 2002); Kenny and Winer (2006); Aidt and Jensen (2009a b); Profeta et al. (2013)).

Several general factors of relevance for the preferred tax mix have been identified and offer a helpful starting point to reflect on the impact of direct democracy on equilibrium tax policies (Hettich and Winer, 1984; Kenny and Winer, 2006): For example, the relative size of tax bases matters since a larger tax base reduces the political resistance for raising an additional unit of revenue from the respective tax. In our context, another important factor determining the equilibrium tax mix is the link between the tax burden 
imposed on voters and the resulting opposition against representative legislators. Under representative democracy, political opposition materializes through expected vote losses in the next election. This link could be influenced, for example, by a low visibility of taxes or by shifting the burden of tax to non-voters such as taxpayers in other jurisdictions, to a higher level of government (Hettich and Winer, 1984) or to taxpayers without voting rights (Aidt and Jensen, 2009a). The implementation of direct democracy substantially widens the scope of voters for effective opposition. Citizens now command over an additional sanction beyond the threat of punishment in the next (possibly distant) election. In contrast to the right of choosing the legislator once for a full legislative term, this sanction can be used frequently over the whole term. Instead of voting on a candidate's or party's policy package announced for the coming legislative period voters can decide on single policy issues continuously.

The general expectation that initiatives strengthen the median voter's power to influence budgetary outcomes should obviously also hold for the tax mix. Voters can make use of the additional channel of opposition to correct the tax mix towards the preferred structure. Importantly in the institutional context of Germany, this power shift is not necessarily conditional on the existence of comprehensive referenda power covering tax laws directly. Even if - as it is the case for German municipalities - voter initiatives must not relate to the budget and hence taxation immediately ("fiscal-taboo") they could be used to sanction a non-preferred tax mix. Voter initiatives impact on collective decisions through different channels (Matsusaka, 1995): They limit the leeway of legislators for vote trading among elected representatives, they reduce committee agenda setting power, they offer a better source of information on voter preferences and they can function as control device preventing legislator shirking or caring for special interest groups. Hence, with initiatives and referenda voters command over a weapon to hit back on spending projects if they perceive the tax mix as inappropriate. This is potentially costly for representative politicians since they are decreasingly able to realize political benefits on the spending side through financing favours for special interest groups or administrative slack. To limit 
these costs, legislators might be forced to stronger take account of voter preferences for the tax side.

In the institutional context of German municipalities this implies a clear hypothesis. Municipalities have tax setting autonomy with respect both to property taxes on real estates and a trade tax imposed on the business sector above a certain threshold. Although the economic incidence of both taxes is unclear (Fuest et al., 2013), the perceived tax burden is strongly asymmetric: the property taxes have a wide coverage while the trade tax imposes a visible burden only on a very small group of the electorate. Hence, we hypothesize that direct democracy with its reduced political influence of minority interest groups will shift the tax mix away from property taxes (and the median voters) towards business taxes (and the taxation of minorities).

The paper is structured as follows: In Section 2 we summarize the German institutional setting and the Bavarian institutions of direct democracy. In subsequent Section 3 we describe the data and develop our identification strategy. Section 4 presents our empirical findings and performs several robustness checks, followed by conclusions in Section 5 .

\section{Institutional Details}

\subsection{Fiscal institutions in Bavaria}

As in all German states, municipalities in Bavaria are responsible for the provision of important public goods to citizens such as kindergartens, elementary schools, utility and infrastructure facilities, local streets, athletic areas and basic health care. Total annual expenditure for an average municipality amounted to around 2,200 Euros per capita in 2011. This spending is partly financed through tax revenue (around $40 \%$ of revenue), while the rest depends on fees, property income or payments through both block and special purpose grants received mainly from the state of Bavaria (and to a smaller extent from the federal level, for details see Bayerisches Staatsministerium der Finanzen (2013)). As typical for Germany's cooperative federalism, these payments have a strongly 
equalizing character and benefit particularly those municipalities with a poor revenue situation. As a consequence, those municipalities that successfully generate economic growth and tax revenues are confronted with an implicit tax through the reduction of received grants.

On the taxation side, some $44 \%$ of revenue comes from shared taxes (Table 1). Municipalities receive predefined shares of VAT and income taxes without any autonomy to set e.g. surcharges on these country-wide taxes. The rest of tax revenue is, however, under local discretion. This autonomous revenue is generated through two sources: property taxes on land and property ("Grundsteuer A and B") $]^{3}$ and tax on local businesses ("Gewerbesteuer", also called the trade tax). For these three taxes, the tax bases are uniformly defined nationwide, but municipalities are free to decide the tax rate through the definition of a tax multiplier ("Hebesatz"), which is applied to the federal rate ("Steuermesszahl") fixed for all municipalities by the central government. $4^{4}$

Thus, we have a system of fiscal federalism with both extensive revenue sharing and far-reaching equalization of differences in the jurisdictions' financial capacities, which imply complex interactions between different government layers. The clear-cut distinction between own source revenue (with full authority over deciding the policy) and nondiscretionary revenue, however, makes this institutional setting particularly attractive for for research question. There are two main reasons. First, with partial autonomy municipalities are left with a few policy tools (e.g. property and business tax rates), which are both clearly observable and contain a good deal of variation across towns. Thus it is easy to test the governments' fiscal reaction to certain political phenomena (e.g. whether direct democracy affects the level of taxation). Second, as discussed in the introduction, the perceived tax burden of the (only) two types of taxes that generate own revenues are

\footnotetext{
${ }^{3}$ As presented in Table 1 municipalities set two different multipliers on agricultural land (rate A) and all other property (rate B) generating about $1 \%$ and $17 \%$ of local autonomous revenue respectively. Since the tax on agricultural land is only a marginal source of funding, we will henceforth concentrate only on tax rate $\mathrm{B}$ and refer to it as the property tax.

${ }^{4}$ The nationwide rate for the local business tax is 3.5\% (5\% before 2008 (Fossen and Bach, 2008)) which is then multiplied by the locally set multiplier, for our sample, ranging from $230 \%$ to $600 \%$. Likewise for the property taxes, a multiplier of up to $800 \%$ is applied to a federally set rate of $0.3-1 \%$ depending on property type and population size.
} 
clearly asymmetric: the property tax has a wide coverage while the business tax (visibly) imposes a burden on a fairly small group of the electorate $5^{5}$ Thus it is feasible to test not only the absolute (i.e. level of taxes), but also the relative effect (i.e. structure of taxes) of direct democracy on taxation.

The local business tax (or equivalently: local trade tax) is the most important profit tax in Germany generating more than 50\% of total business tax revenue (Fuest et al., 2013$)$. Although municipalities cannot keep the full revenues (they have to transfer a share from their trade tax proceeds to state and central government, called "Gewerbesteuerumlage"), the remaining amount is still the most significant source of autonomous revenue for municipalities generating more than half of their tax revenue on average (Table 1). Regarding its incidence, the business tax applies to both corporate and non-corporate firms. In practice, however, sole proprietors and partners of unincorporated firms benefit from a tax-free basic allowance. Moreover, since 2001 these firms are allowed to credit the local business tax liability up to a certain threshold against their personal income tax liability (Fossen and Bach, 2008). Additionally, certain liberal professions such as physicians, lawyers, architects, journalists, as well as most firms in agricultural and public sectors are exempt from the local business tax. Therefore, the local business tax is a tax mainly on corporations arguably with a perceived burden only on a very small group of voters (e.g. business owners).

In contrast, the (non-agricultural) property tax has a much wider coverage as this is paid either by property owners or are directly passed over to the tenants via operating costs (Bundesministerium der Justiz, 2004), and, thus, have a higher visibility for voters. As presented in Table 1, the property tax generates about $17 \%$ of local autonomous revenue.

\footnotetext{
${ }^{5}$ While the formal incidence of a tax is not informative on the economic incidence the former is nevertheless highly relevant for voter awareness for the burden of a tax.
} 


\subsection{Direct democratic institutions}

In 1990s most German states went through a series of reforms introducing elements of direct democracy at the local level. These reforms were implemented independently from each other, and, thus, contained a substantial degree of variation across states. A remarkable case among these state-level reforms was the direct democratic reform in Bavaria ${ }^{6}$ Rather than a change imposed by politicians (as in most other states), here the reform came bottom-up through the right of the citizen initiative at the state level. Despite significant barriers, a popular mobilization in 1995 collected nearly 1.2 million signatures comfortably passing the requirements to initiate a state-wide referendum (around 900,000 signatures (10\% threshold) were to be collected in two weeks time) demanding direct democracy at the local level. The initiative was implemented as a referendum later that year collecting 57.8\% "Yes" votes (Verhulst and Nijeboer, 2008).

Due to their strong roots, the Bavarian direct democratic institutions turned out to the most comprehensive ones among German states both in terms of their legislative openness (Asatryan, 2014) and their exhaustive usage in practice (Figure 1). This is the main reason for us to concentrate on Bavarian municipalities.

The 1995 referendum introduced Article 18 to the Municipal Law of the Free State of Bavaria ("Gemeindeordnung für den Freistaat Bayern") which defines the direct democratic legislation at the municipal level: Voters can launch a citizen-initiative ("Bürgerbegehren") for a referendum ("Bürgerentscheid") with respect to an issue within the competencies of the municipality. Initiatives are not allowed to question the internal organization of the municipal administration, competencies exclusively granted to the mayor by law, the legal affairs of municipal council members, the mayor and municipal employees, and the budget bylaws (i.e. the fiscal-taboo). An initiative successfully leads to a referendum if it is supported by a sufficient number of signatures from municipal residents. These signature requirements depend on the population size of the munici-

\footnotetext{
${ }^{6}$ The discussion of Bavarian reforms is based on Asatryan et al. (2013). See Asatryan (2014) for a discussion of local-level direct democratic institutions across all German states.
} 
pality, and Bavaria is the only state with no time limit for signature collection. Within a month after submitting the application for a referendum, the municipal council has to decide whether the conditions for a lawful referendum are fulfilled. In this case, the referendum has to be conducted no later than three months after the council decision and is implemented under the will of the simple majority. In addition to the citizen-initiative, Bavarian law also allows for the council-initiative ("Ratsreferendum"), which is a referendum called by city councils (on average about a tenth of all initiatives). It is important to point out here that an approved referendum has the legal effects of a municipal council decision; it can be reversed only with another referendum on the same question within a year from the first referendum. Thus, the introduction of direct democracy in Bavarian municipalities in 1995 enabled citizens to conditionally substitute the legislative functions of elected municipal council members.

Subsequent to its establishment, local direct democracy flourished in Bavaria and particularly in the first years, when between 1995 and 1999 more than 1,000 initiatives had taken place in all of the 2099 Bavarian municipalities (Figure 2 shows the annual evolution of initiatives and referenda in Bavaria). This activity was significantly dampened after quorum requirements were introduced to the law in 1999.7 The observation that higher signature or quorum requirements reduce the intensity of direct democratic control is crucial for our identification strategy developed below. Such evidence that higher institutional requirements strongly reduce the number of popular initiatives over all German states is presented by Asatryan (2014). Nevertheless, in most years since then more than one hundred municipal initiatives take place every year. Overall, in the post-reform period, between 1995 and 2011, there have been around 2500 initiatives in all Bavarian municipalities roughly half of them reaching to the polls as referenda.

\footnotetext{
${ }^{7}$ Initially, this quorum requirement did not exist. The participation rate in referenda was consistently lower than municipal elections (Scarrow, 1999). This observation may explain why the Constitutional Court of Bavaria ruled the lacking quorum requirement as unconstitutional so that the Bavarian state parliament had to adjust the Municipalities Law accordingly. The new quorum requirement took effect from 1 April 1999 onwards. Like the signature requirement, the quorum requirement depends on the size of the municipality (Table 4 summarizes the size dependent signature and quorum requirements).
} 


\section{Data and Identification}

The sample consists of a balanced panel of the universe of 2099 Bavarian municipalities for the period between 1980 and 2011. The main fiscal variables of interest are the multipliers on the two types of local property taxes and the multiplier on local business tax as discussed in Section 2. We complement these budgetary statistics with data on direct democratic activity in Bavarian municipalities, that is detailed data (among other including the date, location, topic, type, and result) on all of the 2437 initiatives and 1303 referenda which took place in Bavaria since the 1995 reform (and until 2011, the last point of observation in our dataset). Additionally, a standard set of control variables is collected to control for demographic (total population and share of working age population), political (municipal election dummy and ideological differences at local councils) and economic (share of agricultural and mining areas) factors. Since the dependent variables are the two locally set tax rates, we also want to control for their relative tax bases. Thus we correspondingly include variables capturing the number of residential buildings per $\mathrm{km}^{2}$ and the share of commercial area in total municipal area. 8

Following Asatryan et al. (2013) we specify a two-way approach. We start by simply studying the relation between taxes and observed direct democratic activity, and, then extend the approach to a more convincing quasi-experimental identification. The first "selection-on-observables" type of model takes the following form:

$$
y_{i t}=\alpha+\beta_{1} \cdot R_{i t}+\beta_{2} \cdot C_{i t}+\mu_{i}+\eta_{t}+\epsilon_{i t},
$$

where $y$ is the tax variable of interest, $R$ is a dummy variable indicating whether a referendum has taken place in municipality $i$ in year $t, C$ is the set of control variables specified above, $\mu$ and $\eta$ are town and year fixed effects, and $\epsilon$ is the error term. We discuss the results from this selection on observables approach in Section 4.1 .

\footnotetext{
${ }^{8}$ Table 2 provides the basic statistics of the variables used in the analysis. Additionally, the last two columns of Table 4 present the variation in tax rates and the distribution of towns by population categories classified according to the thresholds in signature and quorum requirements.
} 
One problematic aspect of the selection on observable approaches is possible endogeneity. We therefore shift in a second step the focus from observed direct democratic activity to the underlying legislation. This shift of focus has a number of advantages. First, an emphasis on direct democratic legislation - the ease with which initiatives can be launched - rather than observed activity, allows us to employ a quasi-experimental empirical strategy.

Second, relying on observed initiatives or referenda captures the implications of direct democracy for local taxation only imperfectly. When legislation is more permissive with respect to launch an initiative, local politicians might anticipate more direct democratic activity if they choose tax rates that deviate too much from the median voter's preferences, and therefore comply with her preferences from the outset. Hence, we are likely to underestimate the causal effect of direct democracy if we consider only observed direct democratic activity. To uncover the full causal effect, we need to study the underlying legislative rules that determine the ease with which initiatives or referenda can be launched.

To address the possible endogeneity between taxation and direct democratic activity, we exploit the fact that both signature and quorum requirements decrease discontinuously at certain population thresholds (Table 4), which implies that the causal effect of direct democracy on taxation can be established by means of a regression discontinuity design (Thistlewaite and Campbell, 1960; Imbens and Lemieux, 2008). The idea behind this identification strategy is that there is some degree of randomness in whether municipalities have population sizes just above or just below a given threshold. Allocation of the treatment - more liberal direct democratic institutions - to municipalities should therefore be essentially random in close neighborhoods of a given threshold. This local randomization implies that municipalities with population sizes just above the threshold ("treatment") will have more liberal direct democratic institutions than those below ("control group") even though both groups of municipalities should otherwise be on average identical. 
An important requirement for such identification is that only direct democratic institutions should change at the thresholds. If other simultaneous discontinuities exist, then it would be impossible to identify the sole effect of direct democracy, because the treatment variable would also capture the effect of these other discontinuities. Our institutional context violates this assumption. As discussed by Egger and Köthenbürger $(2010)$ and Ade and Freier (2011), there exist a number of additional institutions that change at these thresholds, such as the size of the local council, wages of elected civil servants, status of the municipality (implying changes in expenditure and revenue duties), certain features of the horizontal fiscal equalization system, etc.9

Therefore, a simple RDD is unlikely to reveal the isolated causal effect of direct democracy but rather a confounded impact of several of the above factors varying with population size. To address this problem we exploit the fact that direct democracy was only introduced in 1995 in Bavaria whereas the above-mentioned population thresholds remained constant in the period under consideration. There is hence a pre- and post-treatment period. We use this over-time variation in direct democracy by studying whether the effect of the discontinuity on taxation differs between the pre- and post-reform periods.

A formal treatment of this difference-in-discontinuity (diff-in-disc) approach and an application using Italian municipalities is available in Grembi et al. (2012). In our setting, the diff-in-disc model can be formulated as:

$$
y_{i t}=\alpha+\beta_{1} \cdot D_{i t} \cdot T_{i}+\beta_{2} \cdot D_{i t}+\beta_{3} \cdot T_{i}+\beta_{4} \cdot f(n p)+\beta_{5} \cdot D_{i t} \cdot g(n p)+\eta_{t}+\epsilon_{i t} \text { if }|n p|<w_{b}
$$

where the dependent variable $y$ is the tax variable of interest as before; $D$ is a dummy variable that is 1 if (normalized) municipal population size is above a given threshold $\sqrt{10} T$ is a dummy variable that equals 1 starting from the year 1995 (the introduction of direct

\footnotetext{
${ }^{9}$ There are a few additional size-dependent rules of more minor importance or ones that apply to towns with less than 10,000 inhabitants, which will not affect our results. For a detailed discussion see Ade and Freier (2011).

${ }^{10}$ Note that, when calculating the treatment dummy, the population numbers are taken from the previous year of the last election, since by Bavarian law population figures to be adopted in legal affairs of municipalities are those at six months prior to the last municipal elections.
} 
democracy); $f(n p)$ and $g(n p)$ are polynomials of (normalized) municipal population size ${ }^{11}$ that, respectively, control for all continuous effects of municipal population on fiscal policy and allow for heterogeneous effects to the left and right of the thresholds; and $w_{b}$ is the bandwidth of the window. Following Egger and Köthenbürger (2010), we analyze all thresholds simultaneously by centering the data around a single 0 threshold and hence normalize municipal population size accordingly ${ }_{12}^{12}$ Regarding the choice of the bandwidth size $w_{b}$, there is a trade-off between reducing bias and increasing efficiency. On one hand, limiting the sample to observations very close to the thresholds reduces bias as "treatment" and "control" municipalities are identical in expectation, however with the risk that results will be subject to significant sampling variability. On the other hand, as the window sizes and hence the number of observations increase, the estimates become more efficient, this time, with the risk of violating the assumption that other than the signature and quorum requirement the municipalities are otherwise identical. Equation 2 is therefore estimated along different windows, $w$, of normalized population size ${ }^{13}$

Finally, an important requirement for a valid RDD is that municipalities should not have been able to selectively sort around the thresholds (Lee, 2008) by manipulating the population statistics (Ade and Freier, 2011). Population sizes are calculated by the state-level statistical office (outside of the control of municipal officials), however there might be some leeway through particular municipal (dis)incentives set for new residents to register or moving residents to unregister. Asatryan et al. (2013) tests this assumption by comparing the densities of municipal population sizes at the thresholds. These population

\footnotetext{
${ }^{11}$ In all baseline regressions we use polynomial of up to the fourth degree. In Section 4.2 .4 we test the robustness of our results to the inclusion of other degrees of polynomials.

${ }^{12}$ More formally, the RDD dummy is defined as:

$$
D_{i t}=\left\{\begin{array}{l}
1, \text { if } \quad \ln \left(N_{i t} / N_{d}\right)>0 \\
0, \text { if } \ln \left(N_{i t} / N_{d}\right) \leq 0
\end{array}\right.
$$

where $N_{i t}$ is the population size and $N_{d}$ are the population thresholds specified by columns 2 (for signature requirements) and 3 (for quorum requirements) of Table 4 , which define the normalized population: $n p=\ln \left(N_{i t} / N_{d}\right)$.

${ }^{13}$ We specify 6 different bandwidths ranging from $1 \%$ to $30 \%$ of (normalized) population size on each side of the (normalized) threshold. For summary statistics on the treatment dummy for each of the bandwidths see the bottom six rows of Table 2 .
} 
histograms do not provide evidence of selective sorting. However serious this problem is, violation of the standard no-manipulation assumption is less problematic in our diff-indisc than in other settings as we rely on differences in the effect of the threshold between the pre- and post-treatment period. As long as those municipal characteristics that allow municipalities to manipulate population sizes are time-constant, we will be able to consistently estimate the treatment effect even if there is manipulation. Asatryan et al. (2013) provides a formal test on the time-consistency of such (possible) manipulation with a modified version of McCrary (2008) plots. The results suggest that neither incentives nor ability for manipulation have significantly changed from the pre- to the post-treatment period.

\section{Results}

\subsection{Selection-on-Observables Approach}

Table 3 collects the results for Equation 1. This equation relates observed direct democratic activity - whether a referendum was held in a municipality - to the (log of) two local tax rates. We study both immediate effects, and delayed effects by lagging the referendum dummy up to two years. In order to allow comparisons across tax rates, we report standardized beta coefficients ${ }^{14}$ Standard errors are two-way clustered at the municipality-year and municipality-initiative level ${ }^{15}$

For the (non-agricultural) property tax (Columns 1-4 of of Table 3), the estimated effects of referenda are consistently positive and in almost all models highly significant. In Columns 5-8, we report the results for the business tax rate. We again observe that

\footnotetext{
${ }^{14}$ Standardized beta coefficients show the amount of standard deviations change in the dependent variable per standard deviation change in the regressor.

${ }^{15}$ For those town-year combinations that have hosted more than one initiative a year we introduce additional rows to capture the extra information coming from these multiple initiatives. We therefore cluster the errors at the municipality-initiative level to account for the resulting bias. Note that this technique is used only in the selection-on-observables approach, while in the RDD setup the lowest unit of observation is municipality-year.
} 
more direct democratic activity leads to higher tax rates. The coefficient is consistently significant. Its magnitude is noticeably larger than in those for the property tax.

Overall, these results indicate that direct democracy increases local tax rates. They also indicate that the taxes with narrower bases - in particular the business tax - increase more than taxes with broader bases - in particular the property tax. The differences in beta coefficients are quite substantial too. However, as discussed above, the evidence based on a selection on observable approach, while suggestive, is in or setting subject to endogeneity problems. We therefore revisit in the next section the link between direct democracy and local tax rates with a quasi-experimental methodology.

\subsection{Quasi-experimental analysis}

While we analyzed the link between observed direct democratic activity and local tax rates in the previous section, we shift in this section the focus to the underlying direct democratic legislation to implement a diff-in-disc design. We first offer some graphical evidence using discontinuity plots and then discuss the regression results.

\subsubsection{Graphical Evidence}

The diff-in-disc plots in Figure 3 are constructed by dividing normalized population size into bins of width 0.01 . We then average the outcome variable - each of the two tax rates - within each bin separately for the pre- and post-treatment periods, and then difference the averages. The differenced averages are plotted in the figure. We also provide separate local polynomial plots of the differenced average against normalized population size to the left- and right of the normalized thresholds, using a bandwidth of 0.5 , a cubic degree, and a rectangular kernel. If more permissive direct democratic legislation had a positive effect on tax rates, the effect of the normalized threshold should be larger in the postthan in the pre-treatment period, and hence the differenced averages should display a positive discontinuity at the threshold. 
The plots show that at the normalized threshold, tax rates for the two taxes increases discontinuously. This observation implies that the average increase in tax rates at the normalized threshold is larger in the post- than in the pre-treatment period. Consistent with the evidence from the selection on observables approach, it appears that more permissive direct democratic institutions lead to higher tax rates. It is, however, difficult to asses which of the two taxes increases the most as the raw discontinuities are not comparable due to the different bases for each of the taxes, and associated exemptions in the tax codes. We therefore discuss the relative coefficient sizes in the next section, where we collect the diff-in-disc regression results.

\subsubsection{Difference-in-Discontinuity Results}

We present the baseline diff-in-disc regression results in Table 5. First, consistent with the graphical evidence, we find evidence for a positive discontinuity for both tax rates when we use a very small bandwidth, i. e. 1\%. The effect is also significant at this bandwidth for the property tax and the business tax rate. For larger bandwidths, however, the estimates are only significant for the business tax multiplier.

Overall, therefore, we conclude that more lenient direct democratic legislation leads to higher local tax rates. The relative size differences of the estimates also indicate that the effect on the business tax rate is larger than on the property tax rate.

This last finding supports the evidence coming from the selection on observables approach, where the differences between the treatment effects for the business tax and the property tax were quite substantial, too.

\subsubsection{Robustness Checks}

\section{Control variables}

Table6 6 replicates the baseline results after accounting for those control variables already considered in the selection on observables approach in Section 4.1. The conclusions do not change, however. More lenient direct democratic institutions have a positive effect 
on tax rates, especially for smaller bandwidths. However, the estimates only remain significant for larger bandwidths when we consider the business tax rate. In the regressions with bandwidths larger than $2 \%$, the size of the estimated beta is also noticeably larger for the business than for the property tax rate.

\section{Different polynomials}

In Table 7, we study whether the results are robust to the use of different polynomials for the control function. We report regressions with polynomial degrees from one up to five (as indicated above, the benchmark regressions use a quartic polynomial). The estimates are once more in line with the baseline results. For a very small bandwidth of $1 \%$, we find a consistently positive effect of more permissive direct democratic legislation on each of the tax rates, irrespective of the polynomial's degree. However, the coefficient is only consistently positive for the business tax rate. The size of the beta is also typically larger in the business tax regressions compared to the property tax regressions.

\section{Placebo thresholds}

In Table 8, we replicate the baseline regressions with placebo thresholds. The idea is to study whether the observed discontinuities in local tax rates at the true normalized threshold is only an artifact or whether they are indicative of a causal effect. If we were to observe a significant effect at the fake thresholds, there is a chance that the effect in the baseline regressions is indeed an artifact. If, on the other hand, the estimates at the placebo thresholds are insignificant, it is likely that the observed effect in the baseline regressions is causal.

We report results with three different fake thresholds, i. e. at 1000, 2000, and 5000 inhabitants. Reassuringly, the estimated coefficients are typically negative and insignificant. It is hence unlikely that the significant baseline estimates are only due to chance. 


\section{Placebo years}

In Table 9, we report a second set of placebo tests where we let the treatment start in a fake year. More specifically, we split the sample into the pre- (1980-1994) and posttreatment periods (1995-2011), and set the treatment date (wrongly) at 1990 and 2001, respectively. We then re-run Equation 2.

For the regressions with the 1980-1994 subsample, we observe typically insignificant effects. The exception is the property tax rate, where we observe a significantly negative effect for two bandwidths. While we find a significant effect at this fake treatment year, this cannot explain the significantly positive effect in the baseline regressions. In the 19952011 subsample, as expected, we do not find any significant effects at the fake treatment years.

\subsubsection{Extensions}

\section{Individual thresholds}

In Table 10, we report results where we explore the effect of individual thresholds rather than studying all thresholds jointly. We find for the business tax rate a consistently positive and often significant effect. The only exception is at the 50,000 inhabitants thresholds and when we use a bandwidth of $10 \%$. However, treatment and control municipalities might not be sufficiently comparable for such large bandwidths. In addition, sample sizes are fairly small even for such large bandwidths for the 50,000 threshold, so that it is possible that only a few outliers dominate the estimates

For the property tax, the treatment effect varies between thresholds. For the 10,000 inhabitants threshold, the treatment effect is consistently insignificant. For the 20,000 inhabitants threshold and for larger bandwidths, the treatment effect is significantly positive. For the 30,000 inhabitants thresholds, the treatment effect is significantly negative when we employ a bandwidth of $5 \%$, but insignificant for larger bandwidths. For the 50,000 inhabitants threshold, the treatment effect is significantly positive for $2 \%$ and $5 \%$ bandwidths, but significantly negative at the $10 \%$ bandwidth. Again, the estimate for 
the $10 \%$ bandwidth might be biased due to the relatively large bandwidth, and simultaneously subject to the influence of outliers given the small sample size.

\section{Second stage effects}

In Table 11, we present TSLS results where rather than analyzing the reduced form effects of direct democratic legislation, we use the legislative rules to construct credible instruments for direct democratic activity. The idea is that since the ease of launching an initiative decreases in the signature requirements, we should observe more direct democratic activity in municipalities that have lower signature requirements. At the same time, signature requirements are imposed by state law and thus, conditional on population size, are quasi-exogenous.

Hence, we instrument in the models reported in Table 11 initiatives or referenda with the signature requirements. As expected, in the first-stage (Panel C) we observe that higher signature requirements reduce observed direct democratic activity.

In the second stage, we observe that both initiatives and referenda lead to significantly higher business and property tax rates. The size of the coefficients for both initiatives and referenda is consistently larger for the business tax than for the property tax.

Overall, these TSLS results that consistent with the RDD results. More permissive direct democratic institution lead to an increase in local tax rates and a shift of the local tax mix toward the business tax. What the TSLS model also show is that this effect, at least to some extent, works through actual direct democratic activity. That is, the effect seems to emerge not only because local officials implicitly comply more with the median voter's preferences when direct democratic institutions are more permissive and thereby reducing the need for direct democratic activity, but also because initiatives and referenda themselves lead to higher taxes. 


\section{Conclusion}

We establish in this paper that direct democracy affects both the level and the mix of local taxes. Both observed direct democratic activity and more lenient direct democratic legislation result (i) in an increase of local tax rates and (ii) a relative shift to taxes with narrower bases: from the property tax to the business tax.

These findings indicate that the preferences of (median) voters and legislators diverge. Voters seem to prefer higher levels of taxes than legislators. In the German institutional setting, and in contrast to evidence from countries such as Switzerland and the US, direct democracy apparently leads to more redistributive taxation. Second, voters also seem to prefer to tax narrower bases than legislators. In the German setting, this finding, too, is plausible. The lion's share of the business tax revenues is typically paid by a few large firms. It is likely that these firms have a decisive influence on legislators' tax policy, both by being able to threaten to relocate plants and by co-opting key politicians by e. $\mathrm{g}$. supporting their election campaigns or sponsoring selected public (or private) projects.

By helping to align tax policies closer to the preferences of citizens, the expansion of direct democracy may improve welfare, especially if the reason for low tax rates is that legislators are being co-opted by economically powerful firms. On the other hand, it is not clear whether voters are aware of the full costs of higher tax rates, in particular on such narrow bases as business profits. That is, voters might not fully understand the hidden costs of expanding taxes on business, i. e. increased outward and reduced inward migration of firms and consequently lower employment opportunities. Given our result that direct democracy leads to higher taxation on especially businesses, one task for future work is to analyze whether these effects have undesirable economic consequences. 
Figures and Tables 
Figure 1: Total number of initiatives in German Länder, 1956-2013

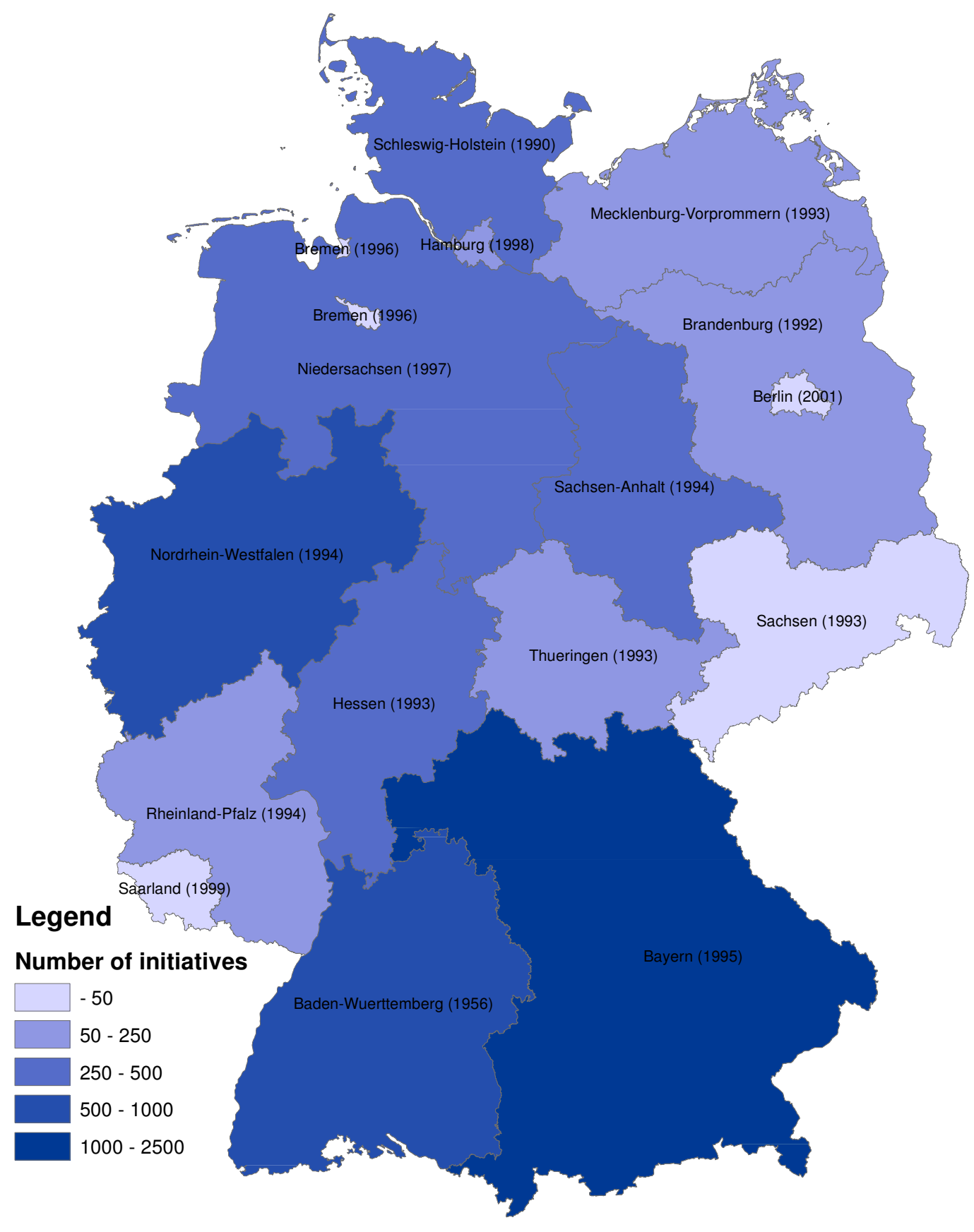

Notes: Total number of local-level initiatives per Land starting from 1956 (the year when two German Länder for the first time adopted initiative legislation) to March, 2013. The year of first initiative (usually coincides with the year of adopting initiative legislation) is in parentheses. 
Figure 2: Annual number of initiatives and referenda in Bavarian towns, 1995-2011

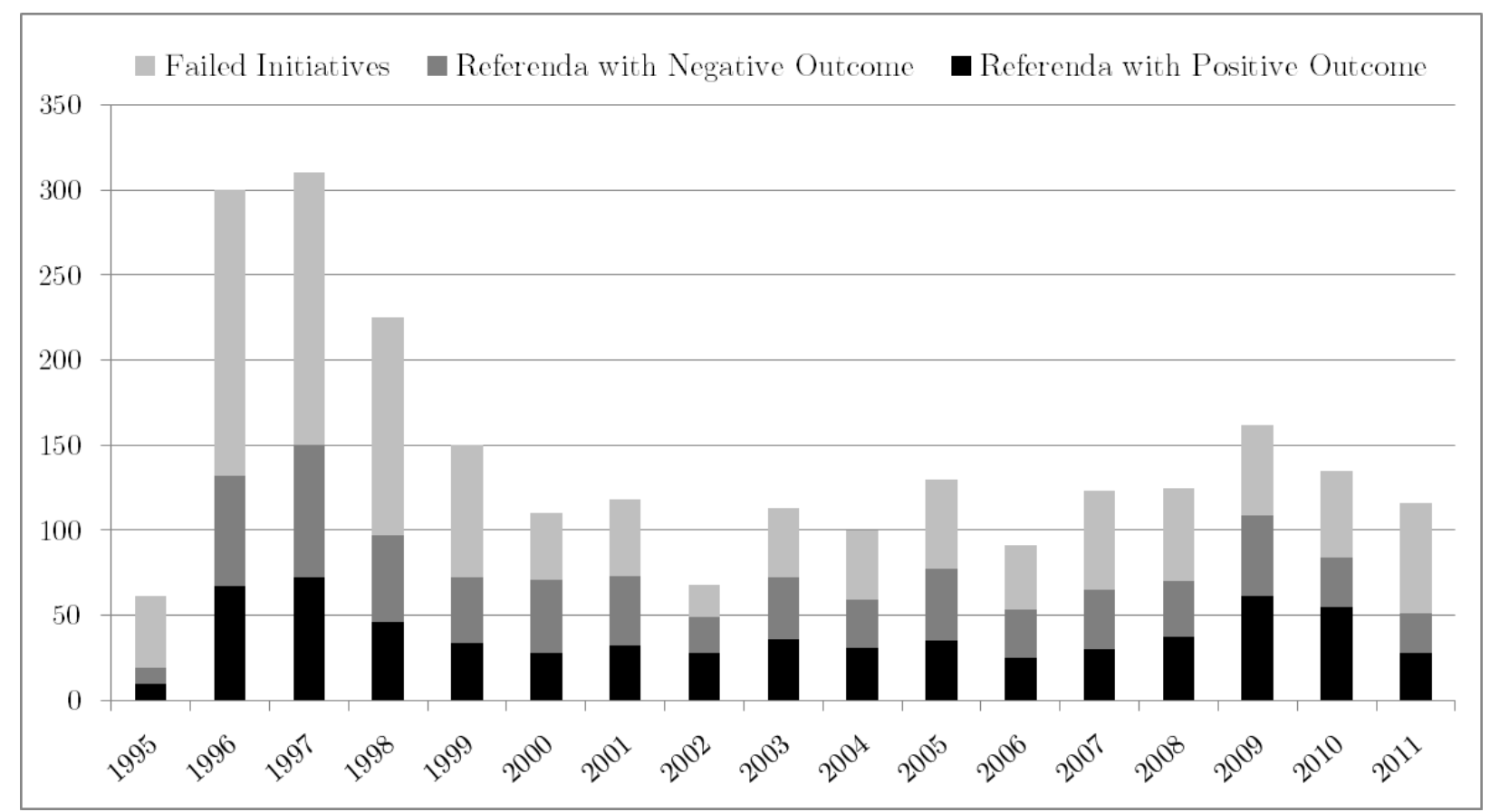

Notes: Annual total local-level initiatives and referenda in all Bavarian municipalities. The initiative legislation was adopted in October 1995 as a result of a state-wide referendum and was revised in April 1999, when additional quorum requirements were introduced. 
Table 1: Revenue structure of Bavarian municipalities in 2012

\begin{tabular}{|c|c|c|}
\hline Revenue Category & Euro, mln. & Share, $\%$ \\
\hline Tax Revenue & 14,016 & $40.8 \%$ \\
\hline Shared Taxes & 6,186 & $44.1 \%$ \\
\hline Autonomous Taxes & 9,356 & $66.7 \%$ \\
\hline Property Tax A & 83 & $0.9 \%$ \\
\hline Property Tax B & 1,603 & $17.1 \%$ \\
\hline Business Tax & 7,620 & $81.4 \%$ \\
\hline Apportionment from the Business Tax & $-1,526$ & $-10.9 \%$ \\
\hline General transfers & 3,177 & $9.2 \%$ \\
\hline User fees & 2,384 & $6.9 \%$ \\
\hline Contributions & 475 & $1.4 \%$ \\
\hline Other current revenues & 6,630 & $19.3 \%$ \\
\hline Investment grants & 1,185 & $3.5 \%$ \\
\hline Borrowing & 1,185 & $3.4 \%$ \\
\hline Other capital revenues & 5,309 & $15.5 \%$ \\
\hline Total Revenue & 34,361 & $100.0 \%$ \\
\hline
\end{tabular}

Source: Own calculations based on data from Bayerisches Landesamt für Statistik und Datenverarbeitung (2013). 
Figure 3: Local diff-in-disc polynomial smooth of municipal tax rates around the normalized threshold

(a) Property Tax Rate

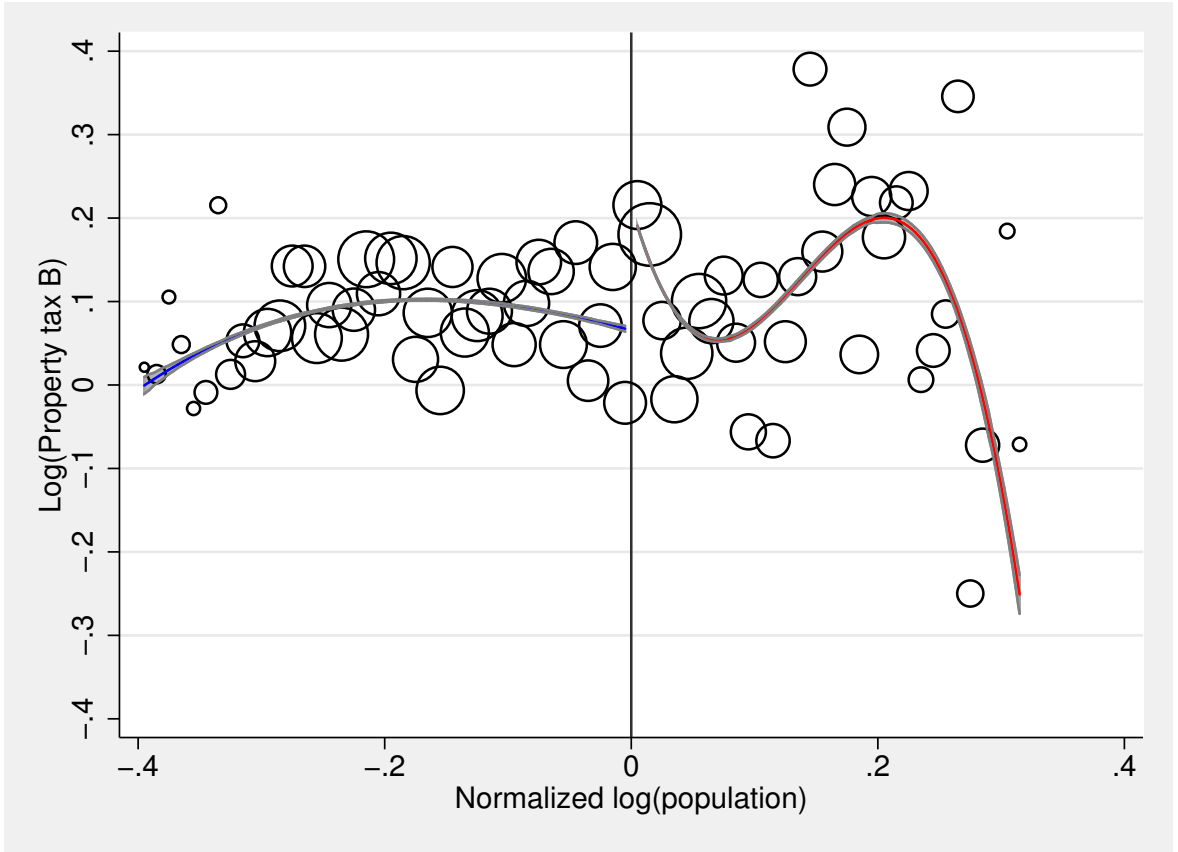

(b) Business Tax Rate

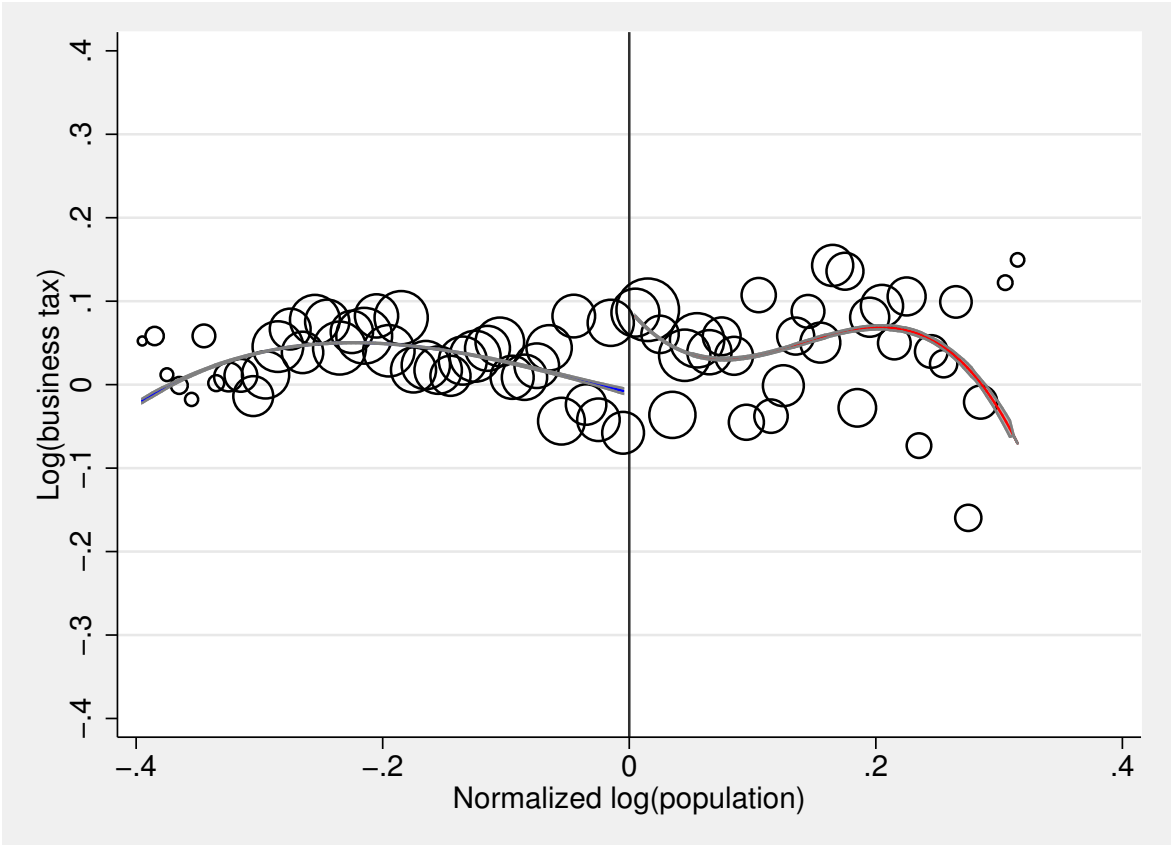

Notes: This figure shows diff-in-disc plots for the change in log property tax and log business tax rates at the normalized threshold from the pre- to the post-treatment period. Observations are averaged within bins of size 0.01 in the scatter plots. The polynomial plots are constructed with a rectangular kernel, a cubic degree, and a bandwidth of 0.5 . The number of observations within bins is used as frequency weights. We also plot $95 \%$ confidence intervals. 


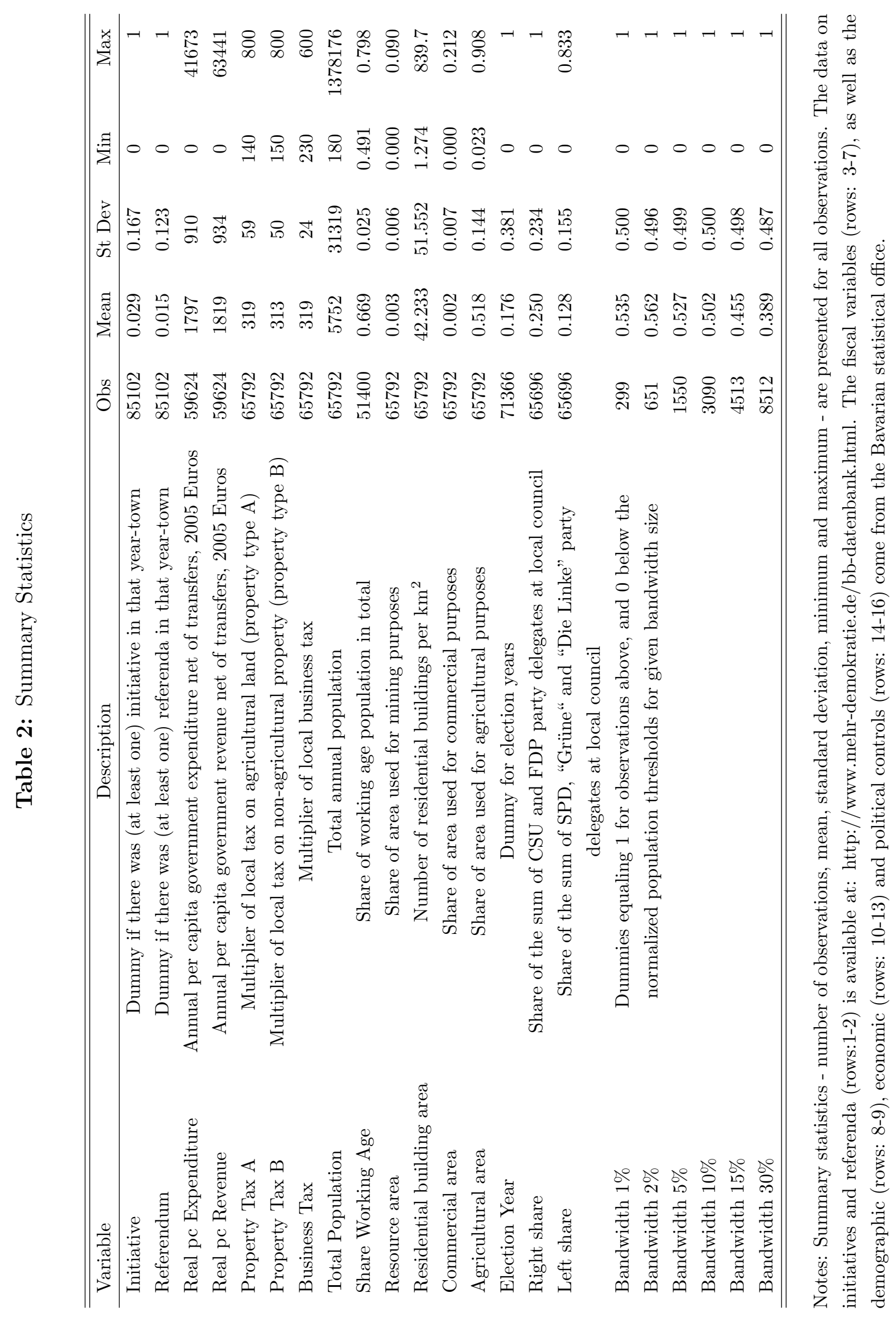


Table 3: The effects of referenda on local tax rates

\begin{tabular}{|c|c|c|c|c|c|c|c|c|}
\hline \multirow{3}{*}{ VARIABLE } & -1 & -2 & -3 & -4 & -5 & -6 & -7 & -8 \\
\hline & \multicolumn{4}{|c|}{ Property Tax Rate } & \multicolumn{4}{|c|}{ Business Tax Rate } \\
\hline & Baseline & Lag-0 & Lag-1 & Lag-2 & Baseline & Lag-0 & Lag-1 & Lag-2 \\
\hline Referendum & $\begin{array}{c}0.005^{* * *} \\
(0.002)\end{array}$ & $\begin{array}{c}0.003 \\
(0.002)\end{array}$ & & & $\begin{array}{c}0.007^{* * *} \\
(0.001)\end{array}$ & $\begin{array}{c}0.006^{* *} \\
(0.001)\end{array}$ & & \\
\hline L1.Referendum & & & $\begin{array}{c}0.005^{* *} \\
(0.002)\end{array}$ & & & & $\begin{array}{c}0.008^{* * *} \\
(0.002)\end{array}$ & \\
\hline L2.Referendum & & & & $\begin{array}{c}0.007^{* * *} \\
(0.003)\end{array}$ & & & & $\begin{array}{c}0.011^{* * *} \\
(0.002)\end{array}$ \\
\hline Ln total population & & $\begin{array}{c}-0.808^{* * *} \\
(0.019)\end{array}$ & $\begin{array}{c}-0.813^{* * *} \\
(0.020)\end{array}$ & $\begin{array}{c}-0.811^{* * *} \\
(0.020)\end{array}$ & & $\begin{array}{c}-0.777^{* * *} \\
(0.010)\end{array}$ & $\begin{array}{c}-0.777^{* * *} \\
(0.010)\end{array}$ & $\begin{array}{c}-0.779^{* * *} \\
(0.010)\end{array}$ \\
\hline Residential build. per $\mathrm{km}^{2}$ & & $\begin{array}{c}0.382^{* * *} \\
(0.000)\end{array}$ & $\begin{array}{c}0.385^{* * *} \\
(0.000)\end{array}$ & $\begin{array}{c}0.382^{* * *} \\
(0.000)\end{array}$ & & $\begin{array}{c}0.220^{* *} \\
(0.000)\end{array}$ & $\begin{array}{l}0.213^{* *} \\
(0.000)\end{array}$ & $\begin{array}{l}0.198^{*} \\
(0.000)\end{array}$ \\
\hline Share of commercial area & & $\begin{array}{l}-0.013 \\
(0.299)\end{array}$ & $\begin{array}{l}-0.011 \\
(0.295)\end{array}$ & $\begin{array}{l}-0.009 \\
(0.293)\end{array}$ & & $\begin{array}{l}-0.012 \\
(0.190)\end{array}$ & $\begin{array}{l}-0.011 \\
(0.188)\end{array}$ & $\begin{array}{l}-0.011 \\
(0.188)\end{array}$ \\
\hline Share of agricultural area & & $\begin{array}{c}-0.055^{* *} \\
(0.026)\end{array}$ & $\begin{array}{c}-0.056^{* *} \\
(0.026)\end{array}$ & $\begin{array}{c}-0.057^{* *} \\
(0.026)\end{array}$ & & $\begin{array}{l}-0.037 \\
(0.013)\end{array}$ & $\begin{array}{l}-0.037 \\
(0.013)\end{array}$ & $\begin{array}{l}-0.036 \\
(0.013)\end{array}$ \\
\hline Share of mining area & & $\begin{array}{l}0.026^{*} \\
(0.375)\end{array}$ & $\begin{array}{l}0.026^{*} \\
(0.368)\end{array}$ & $\begin{array}{l}0.026^{*} \\
(0.365)\end{array}$ & & $\begin{array}{c}0.025 \\
(0.224)\end{array}$ & $\begin{array}{c}0.024 \\
(0.220)\end{array}$ & $\begin{array}{c}0.024 \\
(0.215)\end{array}$ \\
\hline Election year & & $\begin{array}{c}0.287^{* * *} \\
(0.005)\end{array}$ & $\begin{array}{c}-0.034^{* * *} \\
(0.001)\end{array}$ & $\begin{array}{c}-0.035^{* * *} \\
(0.001)\end{array}$ & & $\begin{array}{c}0.217^{* * *} \\
(0.003)\end{array}$ & $\begin{array}{c}-0.083^{* * *} \\
(0.001)\end{array}$ & $\begin{array}{c}-0.084^{* * *} \\
(0.001)\end{array}$ \\
\hline Left share & & $\begin{array}{c}0.003 \\
(0.014)\end{array}$ & $\begin{array}{c}0.002 \\
(0.014)\end{array}$ & $\begin{array}{c}0.001 \\
(0.014)\end{array}$ & & $\begin{array}{c}0.003 \\
(0.008)\end{array}$ & $\begin{array}{c}0.002 \\
(0.008)\end{array}$ & $\begin{array}{c}0.000 \\
(0.008)\end{array}$ \\
\hline Right share & & $\begin{array}{c}-0.004 \\
(0.006) \\
\end{array}$ & $\begin{array}{l}-0.005 \\
(0.006) \\
\end{array}$ & $\begin{array}{l}-0.007 \\
(0.006) \\
\end{array}$ & & $\begin{array}{c}-0.029^{* * *} \\
(0.004) \\
\end{array}$ & $\begin{array}{c}-0.030^{* * *} \\
(0.004) \\
\end{array}$ & $\begin{array}{c}-0.031^{* * *} \\
(0.004) \\
\end{array}$ \\
\hline Observations & 78,752 & 78,656 & 76,204 & 73,752 & 78,752 & 78,656 & 76,204 & 73,752 \\
\hline R-squared & 0.336 & 0.355 & 0.355 & 0.354 & 0.185 & 0.197 & 0.198 & 0.197 \\
\hline $\mathrm{F}$ & 53.96 & 49.61 & 50.06 & 50.10 & 32.84 & 28.93 & 29.51 & 29.96 \\
\hline
\end{tabular}

*** $\mathrm{p}<0.01, * * \mathrm{p}<0.05, * \mathrm{p}<0.1$

Notes: Dependent variable is log Tax Rate specified for each row. Reported coefficients correspond to the standardized beta. Columns 1-2 and 5-6 present results on the simultaneous relation between direct democracy and the two tax rates without and with controls respectively, while each subsequent set of two columns takes one additional backward lag of the direct democracy dummy. All regressions include time and individual fixed effects. Standard errors (in parentheses) are robust to heteroscedasticity and are two-way clustered at municipality-year and municipality-initiative levels. 
Table 4: Signature and quorum requirements by population categories

\begin{tabular}{|c|c|c|c|c|c|c|c|}
\hline \multicolumn{2}{|c|}{$\begin{array}{c}\text { Categories by } \\
\text { Population Size }\end{array}$} & \multirow[t]{2}{*}{$\begin{array}{c}\text { Signature } \\
\text { Requirement } \\
(1995) \\
\% \text { total pop. } \\
10 \%\end{array}$} & \multirow{2}{*}{$\begin{array}{c}\begin{array}{c}\text { Quorum } \\
\text { Requirement } \\
(1999)\end{array} \\
\% \text { eligible votes } \\
20 \%\end{array}$} & $\begin{array}{r}\text { Average } \\
\text { Property-A }\end{array}$ & $\begin{array}{l}\text { Tax Multipli } \\
\text { Property-B }\end{array}$ & $\begin{array}{l}\text { ier, } \% \\
\text { Business }\end{array}$ & Obs. \\
\hline 0 & $<=$ Pop $<10,000$ & & & 321.48 & 313.24 & 317.83 & 59329 \\
\hline 10,000 & $<=$ Pop $<20,000$ & $9 \%$ & $20 \%$ & 297.90 & 301.19 & 328.23 & 4567 \\
\hline 20,000 & $<=\operatorname{Pop}<30,000$ & $8 \%$ & $20 \%$ & 287.46 & 300.80 & 329.28 & 841 \\
\hline 30,000 & $<=$ Pop $<50,000$ & $7 \%$ & $20 \%$ & 264.70 & 309.20 & 339.66 & 504 \\
\hline 50,000 & $<=$ Pop $<100,000$ & $6 \%$ & $15 \%$ & 277.05 & 350.07 & 368.62 & 315 \\
\hline 100,000 & $<=$ Pop $<500,000$ & $5 \%$ & $10 \%$ & 310.71 & 393.11 & 425.21 & 236 \\
\hline 500,000 & $<$ Pop & $3 \%$ & $10 \%$ & 377.79 & 404.10 & 469.46 & 39 \\
\hline
\end{tabular}

Source: Gemeindeordnung für den Freistaat Bayern (version: 24.07.2012).

Table 5: Diff-in-disc: the effect of direct democracy on local tax rates

\begin{tabular}{lccccc}
\hline \hline Bandwidth: & $+/-1 \%$ & $+/-2 \%$ & $+/-5 \%$ & $+/-10 \%$ & $+/-15 \%$ \\
\hline \hline Panel A: Property Tax Rate & & & & & \\
\hline Direct Democracy & $0.385^{* *}$ & 0.189 & 0.020 & -0.023 & -0.014 \\
& $(0.078)$ & $(0.059)$ & $(0.033)$ & $(0.026)$ & $(0.024)$ \\
Observations & 299 & 651 & 1,550 & 3,090 & 4,513 \\
R-squared & 0.272 & 0.217 & 0.143 & 0.137 & 0.141 \\
F & 60.74 & 4.252 & 5.786 & 7.093 & 8.449 \\
\hline \hline Panel B: Business Tax Rate & & & & & \\
\hline Direct Democracy & $0.436^{*}$ & $0.356^{* *}$ & $0.189^{* *}$ & $0.121^{*}$ & 0.086 \\
& $(0.057)$ & $(0.037)$ & $(0.018)$ & $(0.014)$ & $(0.013)$ \\
Observations & 299 & 651 & 1,550 & 3,090 & 4,513 \\
R-squared & 0.203 & 0.107 & 0.064 & 0.051 & 0.054 \\
F & 182.0 & 4.069 & 4.022 & 3.167 & 3.731 \\
\hline \hline
\end{tabular}

${ }^{* * *} \mathrm{p}<0.01,{ }^{* *} \mathrm{p}<0.05,{ }^{*} \mathrm{p}<0.1$

Notes: Dependent variable is log Tax Rate specified for each panel. Reported coefficients correspond to the standardized beta. Direct democracy is the interaction term between the the Treatment Dummy (equaling 0 for observations within the lower bandwidth of the population thresholds, and 1 within the upper bandwidth) and the 1995 Dummy (equaling 1 for the years 1995 and above, and 0 otherwise). Population size of up to the fourth polynomial is included as a control separately for the two sides of the threshold (coefficients not reported). All regressions include time fixed effects. Standard errors are robust to heteroscedasticity and are clustered at municipality level. 
Table 6: Diff-in-disc: the effect of direct democracy on local tax rates controlling for covariates

\begin{tabular}{lccccc}
\hline \hline Bandwidth: & $+/-1 \%$ & $+/-2 \%$ & $+/-5 \%$ & $+/-10 \%$ & $+/-15 \%$ \\
\hline \hline Panel A: Property Tax Rate & & & & & \\
\hline Direct democracy & $0.385^{* *}$ & 0.134 & -0.010 & -0.053 & -0.024 \\
& $(0.072)$ & $(0.056)$ & $(0.032)$ & $(0.024)$ & $(0.023)$ \\
Observations & 299 & 651 & 1,550 & 3,090 & 4,513 \\
R-squared & 0.467 & 0.333 & 0.229 & 0.226 & 0.219 \\
F & 582.0 & 7.170 & 5.774 & 5.974 & 7.661 \\
\hline \hline Panel B: Business Tax Rate & & & & & \\
\hline Direct democracy & $0.337^{*}$ & $0.255^{*}$ & $0.158^{* *}$ & 0.088 & 0.082 \\
& $(0.048)$ & $(0.032)$ & $(0.017)$ & $(0.013)$ & $(0.012)$ \\
Observations & 299 & 651 & 1,550 & 3,090 & 4,513 \\
R-squared & 0.355 & 0.348 & 0.240 & 0.222 & 0.189 \\
F & 35.33 & 5.846 & 2.701 & 3.637 & 4.103 \\
\hline \hline
\end{tabular}

*** $\mathrm{p}<0.01,{ }^{* *} \mathrm{p}<0.05,{ }^{*} \mathrm{p}<0.1$

Notes: Dependent variable is log Tax Rate specified for each panel. Reported coefficients correspond to the standardized beta. Direct democracy is the interaction term between the the Treatment Dummy (equaling 0 for observations within the lower bandwidth of the population thresholds, and 1 within the upper bandwidth) and the 1995 Dummy (equaling 1 for the years 1995 and above, and 0 otherwise). Population size of up to the fourth polynomial is included as a control separately for the two sides of the threshold (coefficients not reported). All regressions include time fixed effects. A full set of control variables as specified in Equation 1 is included in all regression(results not reported). Standard errors are robust to heteroscedasticity and are clustered at municipality level. 
Table 7: Diff-in-disc: the effect of direct democracy on local tax rates with different population polynomials

\begin{tabular}{|c|c|c|c|c|c|}
\hline Bandwidth: & $+/-1 \%$ & $+/-2 \%$ & $+/-5 \%$ & $+/-10 \%$ & $+/-15 \%$ \\
\hline \multicolumn{6}{|c|}{ First Polynomial } \\
\hline \multirow[t]{2}{*}{ Property Tax } & $0.440^{* *}$ & 0.220 & 0.021 & -0.029 & -0.017 \\
\hline & $(0.074)$ & $(0.058)$ & $(0.033)$ & $(0.026)$ & $(0.024)$ \\
\hline \multirow[t]{2}{*}{ Business Tax } & $0.405^{*}$ & $0.332^{* *}$ & $0.184^{* *}$ & $0.119^{*}$ & 0.085 \\
\hline & $(0.054)$ & $(0.037)$ & $(0.018)$ & $(0.014)$ & $(0.013)$ \\
\hline Observations & 299 & 651 & 1,550 & 3,090 & 4,513 \\
\hline \multicolumn{6}{|c|}{ Second Polynomial } \\
\hline \multirow{2}{*}{ Property Tax } & $0.482^{* * *}$ & 0.223 & 0.029 & -0.023 & -0.015 \\
\hline & $(0.074)$ & $(0.058)$ & $(0.033)$ & $(0.026)$ & $(0.024)$ \\
\hline \multirow[t]{2}{*}{ Business Tax } & $0.439^{*}$ & $0.340^{* *}$ & $0.182^{* *}$ & $0.120^{*}$ & 0.086 \\
\hline & $(0.056)$ & $(0.037)$ & $(0.018)$ & $(0.014)$ & $(0.013)$ \\
\hline Observations & 299 & 651 & 1,550 & 3,090 & 4,513 \\
\hline \multicolumn{6}{|c|}{ Third Polynomial } \\
\hline \multirow[t]{2}{*}{ Property Tax } & $0.474^{* * *}$ & 0.229 & 0.024 & -0.023 & -0.014 \\
\hline & $(0.076)$ & $(0.059)$ & $(0.033)$ & $(0.026)$ & $(0.024)$ \\
\hline \multirow[t]{2}{*}{ Business Tax } & $0.446^{*}$ & $0.363^{* *}$ & $0.187^{* *}$ & $0.122^{*}$ & 0.086 \\
\hline & $(0.056)$ & $(0.037)$ & $(0.018)$ & $(0.014)$ & $(0.013)$ \\
\hline Observations & 299 & 651 & 1,550 & 3,090 & 4,513 \\
\hline \multicolumn{6}{|c|}{ Fourth Polynomial (benchmark) } \\
\hline \multirow[t]{2}{*}{ Property Tax } & $0.385^{* *}$ & 0.189 & 0.020 & -0.023 & -0.014 \\
\hline & $(0.078)$ & $(0.059)$ & $(0.033)$ & $(0.026)$ & $(0.024)$ \\
\hline \multirow[t]{2}{*}{ Business Tax } & $0.436^{*}$ & $0.356^{* *}$ & $0.189^{* *}$ & $0.121^{*}$ & 0.086 \\
\hline & $(0.057)$ & $(0.037)$ & $(0.018)$ & $(0.014)$ & $(0.013)$ \\
\hline Observations & 299 & 651 & 1,550 & 3,090 & 4,513 \\
\hline \multicolumn{6}{|c|}{ Fifth Polynomial } \\
\hline \multirow[t]{2}{*}{ Property Tax } & $0.350^{*}$ & 0.19 & 0.024 & -0.022 & -0.016 \\
\hline & -0.08 & -0.059 & -0.033 & -0.026 & -0.024 \\
\hline \multirow[t]{2}{*}{ Business Tax } & $0.414^{*}$ & $0.356^{* *}$ & $0.196^{* *}$ & $0.124^{*}$ & 0.086 \\
\hline & -0.058 & -0.037 & -0.018 & -0.014 & -0.013 \\
\hline Observations & 299 & 651 & 1,550 & 3,090 & 4,513 \\
\hline
\end{tabular}

*** $\mathrm{p}<0.01,{ }^{* *} \mathrm{p}<0.05,{ }^{*} \mathrm{p}<0.1$

Notes: Table presents regressions for up to the fifth polynomial of (normalized) population size specified for each panel. Dependent variable is log Tax Rate specified for each row. Reported coefficients correspond to the standardized beta. Direct democracy is the interaction term between the the Treatment Dummy (equaling 0 for observations within the lower bandwidth of the population thresholds, and 1 within the upper bandwidth) and the 1995 Dummy (equaling 1 for the years 1995 and above, and 0 otherwise). All regressions include time fixed effects. Standard errors are robust to heteroscedasticity and are clustered at municipality level. 
Table 8: Diff-in-disc: the effect of placebo thresholds on local tax rates

\begin{tabular}{lccccc}
\hline \hline Bandwidth: & $+/-1 \%$ & $+/-2 \%$ & $+/-5 \%$ & $+/-10 \%$ & $+/-15 \%$ \\
\hline \hline Panel A: 1 Thousand & & & & & \\
\hline Property Tax & -0.0405 & -0.0174 & -0.0014 & 0.0101 & 0.00637 \\
Business Tax & 0.00256 & 0.0273 & $0.0297^{*}$ & 0.0067 & 0.0078 \\
Observations & 370 & 854 & 2,416 & 4,668 & 6,931 \\
\hline \hline Panel B: 2 Thousand & & & & & \\
\hline Property Tax & -0.0542 & $-0.0858^{*}$ & -0.030 & 0.0038 & -0.0021 \\
Business Tax & -0.0341 & -0.0251 & -0.0117 & -0.0031 & 0.00262 \\
Observations & 620 & 1,200 & 2,882 & 5,759 & 8,721 \\
\hline \hline Panel C: 5 Thousand & & & & & \\
\hline Property Tax & -0.0569 & -0.0186 & -0.0158 & 0.00998 & 0.00393 \\
Business Tax & 0.00323 & -0.003 & -0.0131 & -0.007 & -0.006 \\
Observations & 466 & 873 & 2,057 & 4,080 & 5,862 \\
\hline \hline
\end{tabular}

*** $\mathrm{p}<0.01, * * \mathrm{p}<0.05, * \mathrm{p}<0.1$

Notes: Table presents regressions for placebo thresholds at 1-, 2- and 5- thousand in each panel. Dependent variable is log Tax Rate specified for each row. Reported coefficients correspond to the standardized beta. Direct democracy is the interaction term between the the Treatment Dummy (equaling 0 for observations within the lower bandwidth of the population thresholds, and 1 within the upper bandwidth) and the 1995 Dummy (equaling 1 for the years 1995 and above, and 0 otherwise). Population size of up to the third polynomial is included as a control separately for the two sides of the threshold (coefficients not reported). All regressions include time fixed effects. Standard errors are robust to heteroscedasticity and are clustered at municipality level. 
Table 9: Diff-in-disc: the effect of population thresholds on local tax rates with placebo years

\begin{tabular}{lccccc}
\hline \hline Bandwidth: & $+/-1 \%$ & $+/-2 \%$ & $+/-5 \%$ & $+/-10 \%$ & $+/-15 \%$ \\
\hline \hline Panel A: Placebo year 1990 & & & & & \\
Sample: 1980-1994 & & & & & \\
\hline Property Tax & -0.0236 & $-0.153^{* *}$ & $-0.111^{*}$ & -0.0238 & -0.0156 \\
Business Tax & 0.12 & 0.0061 & 0.0102 & 0.0184 & 0.0273 \\
Observations & 153 & 299 & 756 & 1,407 & 2,034 \\
\hline \hline Panel B: Placebo year 2001 & & & & & \\
Sample: 1995-2011 & & & & & \\
\hline Property Tax & 0.0322 & 0.0412 & 0.0412 & 0.00245 & -0.0073 \\
Business Tax & 0.0149 & 0.00121 & 0.0343 & -0.0047 & -0.008 \\
Observations & 146 & 352 & 794 & 1,683 & 2,479 \\
\hline \hline
\end{tabular}

${ }^{* * *} \mathrm{p}<0.01,{ }^{* *} \mathrm{p}<0.05,{ }^{*} \mathrm{p}<0.1$

Notes: Table presents regressions for placebo years of 1990 and 2001 in each panel. Dependent variable is $\log$ Tax Rate specified for each row. Reported coefficients correspond to the standardized beta. Direct democracy is the interaction term between the the Treatment Dummy (equaling 0 for observations within the lower bandwidth of the population thresholds, and 1 within the upper bandwidth) and the 1995 Dummy (equaling 1 for the years 1995 and above, and 0 otherwise). Population size of up to the third polynomial is included as a control separately for the two sides of the threshold (coefficients not reported). All regressions include time fixed effects. Standard errors are robust to heteroscedasticity and are clustered at municipality level. 
Table 10: Diff-in-disc: the effect of direct democracy on local tax rates on some of the thresholds separately

\begin{tabular}{|c|c|c|c|c|c|}
\hline Bandwidth: & $+/-1 \%$ & $+/-2 \%$ & $+/-5 \%$ & $+/-10 \%$ & $+/-15 \%$ \\
\hline \multicolumn{6}{|c|}{ Panel A: 10 Thousand } \\
\hline \multirow[t]{2}{*}{ Property Tax } & 0.302 & 0.155 & -0.021 & -0.157 & -0.125 \\
\hline & $(0.085)$ & $(0.068)$ & $(0.042)$ & $(0.038)$ & $(0.032)$ \\
\hline \multirow[t]{2}{*}{ Business Tax } & $0.646^{* *}$ & $0.435^{* *}$ & $0.214^{*}$ & 0.033 & 0.054 \\
\hline & $(0.059)$ & $(0.034)$ & $(0.019)$ & $(0.017)$ & $(0.015)$ \\
\hline Observations & 210 & 388 & 948 & 1,868 & 2,780 \\
\hline \multicolumn{6}{|c|}{ Panel B: 20 Thousand } \\
\hline \multirow[t]{2}{*}{ Property Tax } & & 0.054 & -0.006 & $0.233^{* *}$ & $0.199^{*}$ \\
\hline & & $(0.066)$ & $(0.064)$ & $(0.038)$ & $(0.039)$ \\
\hline \multirow[t]{2}{*}{ Business Tax } & & $0.374^{* * *}$ & 0.369 & $0.446^{* *}$ & $0.369^{* *}$ \\
\hline & & $(0.034)$ & $(0.051)$ & $(0.029)$ & $(0.030)$ \\
\hline Observations & 57 & 139 & 346 & 768 & 1,054 \\
\hline \multicolumn{6}{|c|}{ Panel C: 30 Thousand } \\
\hline \multirow[t]{2}{*}{ Property Tax } & & & $-0.284^{* * *}$ & -0.011 & 0.083 \\
\hline & & & $(0.017)$ & $(0.032)$ & $(0.031)$ \\
\hline \multirow[t]{2}{*}{ Business Tax } & & & $0.085^{* *}$ & 0.248 & 0.221 \\
\hline & & & $(0.003)$ & $(0.025)$ & $(0.027)$ \\
\hline Observations & 6 & 26 & 86 & 216 & 313 \\
\hline \multicolumn{6}{|c|}{ Panel D: 50 Thousand } \\
\hline \multirow[t]{2}{*}{ Property Tax } & & $0.779^{* * *}$ & $0.717^{* * *}$ & $-0.690^{* * *}$ & 0.162 \\
\hline & & $(0.001)$ & $(0.004)$ & $(0.053)$ & $(0.047)$ \\
\hline \multirow[t]{2}{*}{ Business Tax } & & $0.655^{* * *}$ & $0.594^{* * *}$ & $-0.491^{* *}$ & -0.278 \\
\hline & & $(0.002)$ & $(0.004)$ & $(0.027)$ & $(0.038)$ \\
\hline Observations & 6 & 38 & 90 & 142 & 248 \\
\hline
\end{tabular}

*** $\mathrm{p}<0.01, * * \mathrm{p}<0.05, * \mathrm{p}<0.1$

Notes: Table presents regressions for the 10-, 20-, 30-, and 50- thousand population thresholds separately in each panel. Dependent variable is log Tax Rate specified for each row. Reported coefficients correspond to the standardized beta. Direct democracy is the interaction term between the the Treatment Dummy (equaling 0 for observations within the lower bandwidth of the population thresholds, and 1 within the upper bandwidth) and the 1995 Dummy (equaling 1 for the years 1995 and above, and 0 otherwise). Population size of up to the fourth polynomial is included as a control separately for the two sides of the threshold (coefficients not reported). All regressions include time fixed effects. Standard errors are robust to heteroscedasticity and are clustered at municipality level. 
Table 11: TSLS: The effects of referenda on local tax rates (reduced-form results)

\begin{tabular}{|c|c|c|c|c|c|c|}
\hline & -1 & -2 & -3 & -4 & -5 & -6 \\
\hline & \multicolumn{2}{|c|}{ Lag 0} & \multicolumn{2}{|c|}{ Lag 1} & \multicolumn{2}{|c|}{ Lag 2} \\
\hline \multicolumn{7}{|l|}{ Panel A: Property Tax Rate } \\
\hline \multirow[t]{2}{*}{ Initiative } & $2.496^{* * *}$ & & $2.783^{* * *}$ & & $2.620^{* * *}$ & \\
\hline & $(0.513)$ & & $(0.622)$ & & $(0.533)$ & \\
\hline \multirow[t]{2}{*}{ Referendum } & & $4.848^{* *}$ & & $5.496^{* *}$ & & $4.893^{* *}$ \\
\hline & & $(1.924)$ & & $(2.293)$ & & $(1.973)$ \\
\hline \multicolumn{7}{|l|}{ Panel B: Business Tax Rate } \\
\hline \multirow[t]{2}{*}{ Initiative } & $2.731^{* * *}$ & & $3.051^{* * *}$ & & $2.881^{* * *}$ & \\
\hline & $(0.313)$ & & $(0.385)$ & & $(0.33) 0$ & \\
\hline \multirow[t]{2}{*}{ Referendum } & & $5.306^{* *}$ & & $6.026^{*}$ & & $5.381^{*}$ \\
\hline & & $(1.243)$ & & (1.503) & & (1.301) \\
\hline
\end{tabular}

Panel C: First-Stage Results:

\begin{tabular}{lcccccc} 
Signature Requirement & $-0.101^{* * *}$ & $-0.040^{* *}$ & $-0.113^{* * *}$ & $-0.055^{* * *}$ & $-0.109^{* * *}$ & $-0.069^{* * *}$ \\
& $(0.535)$ & $(0.331)$ & $(0.582)$ & $(0.358)$ & $(0.580)$ & $(0.413)$ \\
& & & & & & \\
\hline Observations & 41,832 & 41,832 & 39,376 & 39,376 & 36,915 & 36,915 \\
\hline \hline
\end{tabular}

${ }^{* * *} \mathrm{p}<0.01,{ }^{* *} \mathrm{p}<0.05,{ }^{*} \mathrm{p}<0.1$

Notes: The table presents Two Stage Least Squares estimates of Equations 1 where the direct democracy dummies, $R$, are instrumented on signature requirement (controlling fro quorum requirements and all other regressors). Dependent variable is log property and business tax rate in panels A and B respectively. First-stage results are presented in Panel C, where the dependent variable is the direct democracy dummy. Reported coefficients correspond to the standardized beta. Columns 1-2 present results on the simultaneous relation between tax rate and the two alternative definitions of direct democracy, while each subsequent set of two columns takes one additional backward lag of the direct democracy dummies. All regressions include time and county fixed effects. A full set of control variables as specified in Equation 1 is included in all regression(results not reported). Standard errors are robust to heteroscedasticity and are clustered at county levels. 


\section{References}

Ade, F. and R. Freier (2011). When can we trust population thresholds in regression discontinuity designs? Discussion Paper 1136, DIW Berlin.

Aidt, S. T. and P. S. Jensen (2009a). Tax structure, size of government, and the extension of the voting franchise in Western Europe, 1860-1938. International Tax and Public Finance 16(3), 362-394.

Aidt, S. T. and P. S. Jensen (2009b). The taxman tools up: An event history study of the introduction of the personal income tax. Journal of Public Economics 93(1), 160-175.

Asatryan, Z. (2014). The indirect effects of direct democracy: Local government size and non-budgetary voter initiatives. Discussion Paper 14-004, ZEW.

Asatryan, Z., T. Baskaran, T. Grigoriadis, and F. Heinemann (2013). Direct democracy and local public finances under cooperative federalism. Discussion Paper 13-038, ZEW.

Ashworth, J., B. Geys, and B. Heyndels (2006). Determinants of tax innovation: The case of environmental taxes in Flemish municipalities. European Journal of Political Economy 22(1), 223-247.

Ashworth, J. and B. Heyndels (2001). Political fragmentation and the evolution of national tax structures in the OECD. International Tax and Public Finance 8(4), 377393.

Ashworth, J. and B. Heyndels (2002). Tax structure turbulence in OECD countries. Public Choice $111(3-4), 347-376$.

Bayerisches Landesamt für Statistik und Datenverarbeitung (2013). Gemeindefinanzen und Realsteuervergleich in Bayern 2012, Ergebnisse der vierteljährlichen Kassenstatistik. Technical report, München. 
Bayerisches Staatsministerium der Finanzen (2013). Der kommunale Finanzausgleich in Bayern. Technical report, München.

Bundesministerium der Justiz (2004). Verordnung über die Aufstellung von Betriebskosten. Technical report, Berlin.

Egger, P. and M. Köthenbürger (2010). Government spending and legislative organization: Quasi-experimental evidence from Germany. American Economic Journal: Applied Economics 2(4), 200-212.

Feld, L. P., G. Kirchgässner, and C. Schaltegger (2010). Decentralized taxation and the size of government: Evidence from Swiss state and local governments. Southern Economic Journal 77(1), 27-48.

Feld, L. P. and J. G. Matsusaka (2003). Budget referendums and government spending: Evidence from the Swiss Cantons. Journal of Public Economics 87(12), 2703-2724.

Feld, L. P. and C. Schaltegger (2012). Die Politische Ökonomik der Besteuerung. Perspektiven der Wirtschaftspolitik 13(1-2), 116-136.

Fiva, J. and J. Rattso (2007). Local choice of property taxation: Evidence from Norway. Public Choice 132(3-4), 457-480.

Fossen, F. and S. Bach (2008). Reforming the German local business tax: Lessons from an international comparison and a microsimulation analysis. FinanzArchiv: Public Finance Analysis 64(2), 245-272.

Fuest, C., A. Peichl, and S. Siegloch (2013). Do higher corporate taxes reduce wages? Micro evidence from Germany. Discussion Paper 13-039, ZEW.

Funk, P. and C. Gathmann (2011). Does direct democracy reduce the size of government? New evidence from historical data, 1890-2000. Economic Journal 121 (557), 1252-1280.

Funk, P. and C. Gathmann (2013). Voter preferences, direct democracy and government spending. European Journal of Political Economy 32(1), 300-319. 
Geys, B. and F. Revelli (2009). Decentralization, competition and the local tax mix: Evidence from Flanders. Working Paper 17, IEB.

Gilla, H. L. and D. R. Haurin (2001). The choice of tax base by local authorities: Voter preferences, special interest groups, and tax base diversification. Regional Science and Urban Economics 31(6), 733-749.

Grembi, V., T. Nannicini, and U. Troiano (2012). Policy responses to fiscal restraints: A difference-in-discontinuities design. Working Paper 3999, CESifo Group Munich.

Hettich, W. and S. Winer (1984). A positive model of tax structure. Journal of Public Economics 24(1), 67-87.

Hettich, W. and S. Winer (1988). Economic and political foundations of tax structure. American Economic Review 78(4), 701-712.

Hettich, W. and S. Winer (1999). Democratic Choice and Taxation: A Theoretical and Empirical Analysis. Cambridge: Cambridge University Press.

Hinnerich, B. T. and P. Pettersson-Lidbom (2012). Democracy redistribution and political participation: Evidence from Sweden 1919-1938. Working paper, Stockholm University.

Imbens, G. W. and T. Lemieux (2008). Regression discontinuity designs: A guide to practice. Journal of Econometrics 142(2), 615-635.

Inman, R. P. (1989). The local decision to tax: Evidence from large U.S. cities. Regional Science and Urban Economics 19(3), 455-491.

Kenny, L. and S. Winer (2006). Tax systems in the World: An empirical investigation into the importance of tax bases, administration costs, scale and political regime. International Tax and Public Finance 12(2-3), 181-215.

Kirchgässner, G. (2000). The effects of fiscal institutions on public finance: A survey of the empirical evidence. In S. L. Winer and H. Shibata (Eds.), Political Economy and 
Public Finance: The Role of Political Economy in the Theory and Practice of Public Economics, pp. 145-177. Cheltenham: Edward Elgar.

Lee, D. S. (2008). Randomized experiments from non-random selection in US House elections. Journal of Econometrics 142(2), 675-697.

Matsusaka, J. G. (1995). Fiscal effects of the voter initiative: Evidence from the last 30 years. Journal of Political Economy 103(3), 587-623.

Matsusaka, J. G. (2005). Direct democracy works. Journal of Economic Perspectives 19(2), 185-206.

McCrary, J. (2008). Manipulation of the running variable in the regression discontinuity design: A density test. Journal of Econometrics 142(2), 698-714.

Pommerehne, W. (1978). Institutional approaches to public expenditures: Empirical evidence from Swiss municipalities. Journal of Public Economics 9(2), 255-280.

Profeta, P., R. Puglisi, and S. Scabrosetti (2013). Does democracy affect taxation? evidence from developing countries. Journal of Comparative Economics 41(3), 684718.

Romer, T. and H. Rosenthal (1979). Bureaucrats versus voters: On the political economy of resource allocation by direct democracy. Quarterly Journal of Economics 93(4), $563-587$.

Scarrow, S. E. (1999). Parties and the expansion of direct democracy: Who benefits? Party Politics 5(3), 356-357.

Thistlewaite, D. and D. Campbell (1960). Regression-discontinuity analysis: An alternative to the ax-post facto experiment. Journal of Educational Psychology 51, 309-317.

Verhulst, J. and A. Nijeboer (2008). Direct democracy: Facts and arguments about the introduction of initiative and referendum. Brussels: Democracy International. 
Volkerink, B. and J. de Haan (1999). Political and institutional determinants of the tax mix: An empirical investigation for OECD countries. Working Paper 99-05, SOM.

Winer, S. and W. Hettich (1991). Debts and tariffs: An empirical investigation of the evolution of revenue systems. Journal of Public Economics 45(2), 214-242. 